\title{
The Recruit from a Depôt Medical Officer's Point of View
}

\author{
Lient.-Colonel C. M. Douglas Hon. Brigade-Surgeon V.C., M.D.
}

To cite this article: Lient.-Colonel C. M. Douglas Hon. Brigade-Surgeon V.C., M.D. (1900) The Recruit from a Depôt Medical Officer's Point of View, Royal United Services Institution. Journal, 44:263, 1-17, DOI: $10.1080 / 03071840009419977$

To link to this article: http://dx.doi.org/10.1080/03071840009419977

\section{曲 Published online: 11 Sep 2009.}

Submit your article to this journal $\pi$

Џ Article views: 5

Q View related articles $\longleftarrow$ 


\section{THE JOURNAL}

\section{ROYAL UNITED SERVICE INSTITUTION.}

$\begin{array}{lll}\text { VoL. XLIV. JANUARY, } 1900 . & \text { No. } 263 .\end{array}$

[Authors alone are responsible for the contents of their respective Papers.]

\section{THE RECRUIT FROM A DEPÔT MEDICAL OFFICER'S POINT OF VIEIV.}

Bj' Licut.-Colonel C. M. DOUGL.AS, V.C., M.D. (HIn. Brigadi-Surgion), Armu Madical Sericice.

Wednesday, October 25th, 1899.

Major-General J. F. MaURICE, C.B., R.A., p.s.c., Commanding Woolwich District, in the Chair.

THE raw recruit is the foundation-stone of the prosperity of the British Army. Perhaps the raw recruit fails to appreciate this fact and to understand his important position. Nevertheless, it is a mere truism to assert, that without him the Army would be impossible, that, if he is a worthless incapable, the whole structure will fall to pieces. The magnetic influence of a brave, enthusiastic, and self-sacrificing leader will be exerted in vain on a band of effete, spiritless conscripts. Let us cxaminc as far as we can, without prejudice, the condition of this foundationstone. The medical officer literally sees more of the recruit than anyone else. He is biased by no motive in accepting or rejecting recruits, and, consistent with the regulations, he conscientiously endeavours to do his best for the Service-in helping to supply "likely young men to serve Her Majesty."

What (speaking in quite unofficial language), asks the philosopher, is the net purport and object of war? And he describes the recruits from the British village of Drumdrudge, " the weakest of whom can stand under thirty stone aroirdupois." (These are ideal recruits. I should be sorry to put thirty stone on the back of an average "special.") These thirty recruits are pitted against thirty from a French village of Drumdrudge, and, at the word "Fire," they blow the souls out of one another.

So war is "destruction." But, we hope, it is destruction of the effete, the ricious, and the degenerate. It is chiefly upon these, directly and indirectly, that the storm bursts. True, many of the brisk, useful craftsmen are also destroyed. The tares and the wheat fall together. Much of what is good and noble is swept away. But the tiger and the ape are

roL. XLIY. 
gradually worked out, and a higher type of humanity comes in slowly in their place. It is a rude but necessary discipline; a harsh, indiscriminating, and uncertain scourge, to be dreaded and aroided if possible-to be done with and forgotten as soon as they can both by victors and vanquished.

$A$ higher religion or a better conception of the precepts of the Founder of our Faith will ultimately render it unnecessary, or rarely resorted to. In place of international warfare, we shall have increasing intestinal strife against the principles of evil, which cause decay, degeneration, and premature death of individuals, communitics, and nations; against evil in its repulsive forms of greed, cruelty, lust, oppression, and selfindulgence.

Slowly adrancing and receding, like the waves of an incoming tide, we are gradually moving higher. But wars, diminishing in frequency and severity, will continue for some xons, in spite of the efforts of the best and noblest amongst us.

To make the destructive spirit as effective as possible, to inspire masses of men with a right spirit of sclf-sacrifice, of confidence in their leaders and themselves, is the aim of all military organisation. We call this martial spirit various names, moral, esprit de corps, , borrowing these words from our martial neighbours. Each nation glorifies its fighting-mien as superior to all others, although most admit that the article " Made in Germany" has considerable merit.

The forcign officer somewhat sarcastically observes, I believe, that "we, the British Nation, have no Army."

He implies, I presume, that we have no military organisation such as the Armies of the Continent, which represent the whole fighting spirit of the nation combined. We have a heterogeneous mixture. A comparatively small collection of highly trained soldiers, which forms a nucleus round which are aggregated bands of armed citizens, inspired with more or less of the martial spirit alluded to, and engrained with varying quantities of military discipline. In the Home District these forces are combined at mancurres in masses apparently homogeneous to the unmilitary eye, but at the remoter military stations each moves in its special sphere, with little combinations for exercises, except perhaps on a small scale.

The nucleus we call the "Army." The revolving satellites are the "Auxiliary Forces," as alluded to at public mectings and social gatherings.

It is the recruit for the Army proper that I will attempt to draw, as I see him : a compact, vigorous, well-developed, and proportioned person, usually denotes a high degree of animal vitality, and of the quality which is known as "hardihood"-most desirable in a soldier. Occasionally great vital force and cncrgy have inspired puny or weakly organisations, such, for example, as William of Orange, Wolfe, Nelson; but these are exceptional instances. The arrested bodily development seems to have given free scope for the growth of spiritual energy of the highest type. Such cases are rare; they may be looked on as "sports," in fact. 


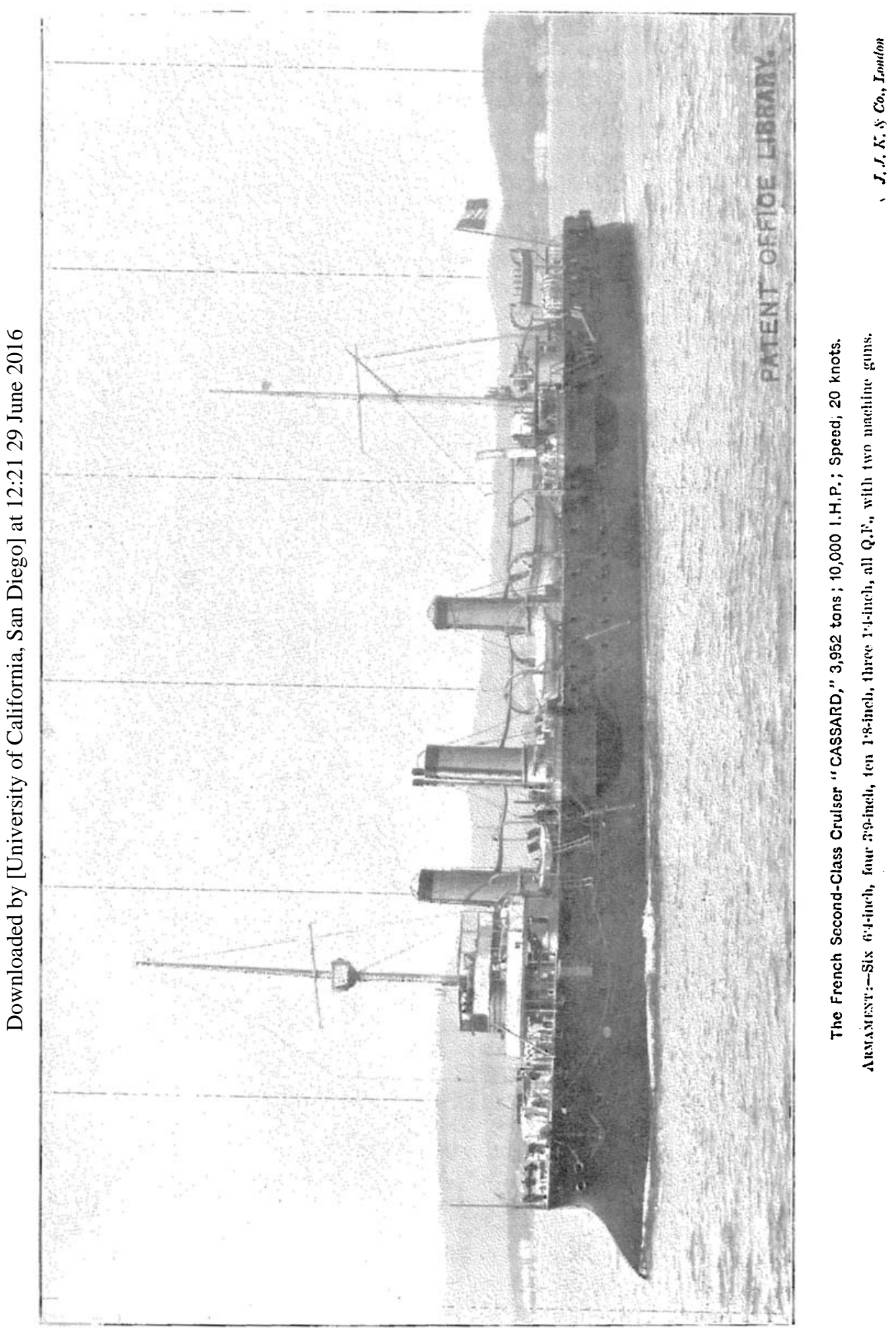


Hardihood then is the first essential of a soldier. Let us examine the raw material at a recruiting centre to sec how far we obtain the vigorous, healthy husk which encloses the grain of vitality; that unknown, mysterious quantity which is variously denominated "vital power," "soul," "courage," "spirit." .

The depot is a remote one, but is above the average of provincial depôts in providing recruits for Her Majesty's regiments.

I have also taken averages from another depot, to which recruits are sent from other districts, as this depôt does not provide a sufficient number of recruits to supply the demands of the regiment of which it is the recruiting centre.

The recruits represent, I believe, the average physical development of the young men who enlist in the Northern District of England, and of Scotland.

About ten in the morning, into a barrack room, furnished with appliances for testing height, weight, and eyesight, a small band of the would-be soldiers of the Queen enter. Two or three may be average, well-developed young men, six or eight sallow nondescript youths, the artisan element being most in evidence. They have a quiet and rather downcast expression as a rule. The most cheerful are those who have served a training or two in the Militia. First their eyesight is tested by their ability to count dots at a required distance. Perhaps one who repents having taken the Queen's shilling wilfully makes a mistake, generally easily detected (lhough occasionally duc to a genuine defect), another will fail through nervousness, and some of the others with apparent perverseness may follow suit, greatly to the disturbance of the recruiting sergeant's peace of mind.

Generally this examination is satisfactorily concluded; each recruit is now carefully scrutinised, much after the fashion of a hunter by a vet. The weight and height of the candidate are first taken, the circumference of his chest at rest, as far as he can be induced to allow his lungs to act naturally. His head and teeth are examined, and the latter are generally found more or less unsound-a perfectly good set of teeth is rare in my experience, except among the agricultural recruits. His lungs and heart are sounded; he is put through his paces-walking, hopping, and various exercises-to show that he has perfect use of all his limbs. His mental qualifications are tested by a few simple questions. A high standard of intelligence is not looked for, though I have known a recruit rejected for "mental deficiency" after he joined his regiment, because when he was asked who was his father, he appeared confused. "It's a wise child that knows his own father."

The standard of intellect in this regiment was high, and though the mode of ascertaining whether the recruit came up to it was somewhat primitive, it was to the point.

The minimum physical standard is low :-

Weight, 115 lbs.

Height, 5 feet $3 \frac{1}{2}$ inches.

Minimum girth of chest, 33 inches.

Age, 18 years. 
This does not represent a fine type of a British male. Nany are enlisted who do not come up to this standard. These are known as "specials," but not in the usual acceptation of the term "special." They are recruits who do not quite come up to the standard of height, weight, or chest measurement; but who are likcly to develop into efficient soldiers. Some of these "specials," who lack perhaps half an inch of the standard of height, are better men than those who surpass it. A short, muscular, weil-formed man, of the type of "Ortheris," makes a most efficient soldier. He is generally more active than a big man, has less to carry in marching, and, as an emirent scientist has pointed out, there are many chances in his favour against his being hit by a bullet, which would disable a bigger soldier. I was rather surprised to find that the average height of a number of recruits rejected by myself for various causes was greater than that of those whom I passed.

An American gentleman, Professor Dudley Sarjent, of Harvard University, took the measurements of the body and limbs of several thousands of American students ranging from sixteen to twenty-six years of age, an equal, or nearly equal, number of each age, and from these measurements had a statue made. It secms to me an important contribution to anthropometry.

The American students are drawn from all classes of the community, prolctarian and patrician (for there is a patrician class in that country, where all men and women are born free and equal), and the statue represents the average physical development of the best of the American youths-a physical standard of youthful manhood which it would be desirable to obtain. If we enlisted an equal, or nearly equal, number of recruits of each age, from eighteen to twenty-six years, we might expect to obtain as good a result or better. Our minimum age is higher, and we reject the recruits who do not come up to a certain standard. Nevertheless, the physical average of our recruits is much lower, chiefly owing to the immature age at which we have to enlist. Here is the average physical development of the British recruit for the purpose of comparison, and these are the measurements :-

American Student.

Age, 22 years 3 months.

Weight, $156 \mathrm{lbs}$.

Height, 5 feet $8 \frac{1}{3}$ inches.

Girth of chest, $34 \frac{1}{3}$ inches minimum, $36 \frac{1}{2}$ maximum.

R. upper-arm, 111 inches.

R. fore-arm, 101 inches.

Brilish Recruit.

Age, 19 years 4 months.

Weight, 126 lbs.

Height, 5 -feet $5 \frac{2}{3}$ inches.

Girth of chest, $33 \frac{1}{2}$ inches minimum, 35 maximum.

R. upper-arm, $10 !$ inches.

R. fore-arm, 91 inches. 
The measurements are taken from a few pages of the recruit registers of two depôts selected haphazard. After I had made up my averages, I had the satisfaction of finding they corresponded within a few fractions of the averages of the recruits for the whole Army as given in the Annual Report for 1897. My averages are a few fractions higher. I think they may be accepted as approxim?tely correct, though I admit my researches in anthropometry are poor and meagre as compared with Dr. Sarjent's.

A writer of a recent book on the "Queen's Service," from the point of view of the private soldier, speaks of the "vagaries" of Army medical officers for accepting or rejecting recruits. The usual average of rejections is a little over one-third; some reject more, others less. A medical officer who is rery "particular" might, I believe, find a sufficient cause for rejecting two-thirds of the raw recruits who come up for examination. Indeed, a case of wholesale rejection came under my notice many years ago. Rather a large batch of some twenty-five or thirty recruits, who had been passed by a civilian practitioner in a town in the Midlands, were rejected by an Army medical oflicer when they camc up for final approval. A short time afterwards I met the officer who had made this wholesale rejection of one hundred per cent. Said I, "Wasn't there one good one in the lot ?"-nce quisquam ex agmine tanto? "No," said he, " every one had something wrong with him."

Insufficient development, a failure to come up to the standards of height, weight, or chest measurements required, give the greatest number of rejections. No doubt many of those whose chest measurement is small and expansion defective have the seeds of latent lung or heart affection. Varicose veins and defects of the lover extremities also cause many rejections. Loss and decay of many teeth cause an uncepected number of rejections. Some of them who have lost their teeth by accident or the use of improper food when getting their second set of teeth, are well-developed strong young men otherwise, who would make good soldicrs in spite of this defect, which may not tell upon them until late in life. They can generally "chaw," as they express it. Indeed, in many of these cases loss of teeth does not seem to be so much a defect as hardened gums an acquisition. But when the deficiency of teeth is associated with a weakly, degenerate frame it is quite another matter.

Looking at him in the totality, the average recruit is not a fine specimen of the animal bimana with a thumb to his wrist. The minimum standard is intended to keep out undesirable recruits; and those who just succecd in passing it, and there arc many of them, are on the verge of the undesirable. It has been said that our stanclaid is higher than that of the recruit of the Armies of Continental nations. The comparison is not quite just. Those nations who have compulsory service may be said to use a net, the meshes of which will not allow the little fishes who may be of use to escape; while the meshes of our net are made as large: as we dare, to capture only the best fish and let the little ones get away.

Enlistment in the British Army is called "voluntary;" but the term is scarcely applicable to a great many of them. The enlistments are "compulsory." The compulsion is exercised by two powerful, invisible 
recruiting sergeants, "Want" and "Hunger." A writer in a recent number of the Fortnigflly Magazine on "Our Boys," says:- "The Army is the last refuge of an honest lad who has failed in life." If so, it must be an unpleasant reflection to the medical officer who rejects some thirty or more per cent. of would-be recruits, that he, condemns those rejected ones todishonest courses. Certainly I have often pondered over the prospects in life of the recruits who have failed to come up to the rather low standard which is required ; "it gives something to think seriously about." What can these rejected ones do to carn a livelihood? Join the ranks of the Hooligans, incapables, and criminals, and enlist in the great army of the "noxious poor," of the Submerged Tenth, which obtrudes itself on one's notice and will not be ignored. Kayce, the historian of the Indian Mutiny of 1857-58, contrasts in striking colours the conditions under which the British youth became a soldier, with those which caused the natives of Hindostan to join the ranks of the army of Jan Cumpani. I hope I may be excused for quoting it. "In Eugland few men enlist into the Army as an honourable profession, or scek it as an advantageous source of subsistence. Few men enter it with any high hopes or pleasturable emotions. 'The recruit has commonly broken down as a civilian. Of ruined fortune and bankrupt reputation, he is tempted, cheated, snared into the Army. Lying placards on the walls, lying words in the pothouse, the gaudy ribbons of Sergeant Kitc, the drum and the fife and the strong drink captivate and enthral him when he is not master of himself. He has quarrelled with his sweetheart or robbed his employer; he has cxhausted the patience of his own people, and the outer world has turned its back upon him, and so he goes for a soldier. As soon as he has taken the shilling he has gone out of the family circle and out of the circle of civil life-he is a thousandth part of a regiment of the Army. Perhaps he has changed his name and stripped himself of his personal identity; anyhow, he is as one dead. Little more is heard of him, and unless it be some doting old mother who best loves the blackest shecp of the flock, nobody wishes to hear. It is often indeed no greater source of pride to an English family to know that one of its members is serving the Queen in the ranks of the Army than to know that one is provided for as a.convict at the national expense."

So wrote Kaye in 1804, the day's of that long service, which some of -our military critics think it would be desirable to re-introduce. The recruit of the present day, as far as 1 know him, does not enlist because he has quarrelled with his swectheart; he loves the sex in the aggregate, not in the particular. If he has robbed his employer, it is not becaluse the latter has advanced him to the responsible position of the care of the till. "What makes you cnlist?" is the question I almost invariably put to the recruit who comes up for examination. At a rough estimate fitty per cent. reply "Out of work," "I had nothing to do." When this powerful motive is not the cause, the answers I receive to my questions are often very vague and uncertain. "I took a liking," "I was tired of my trade," "I had a quarrel with my father-with my brother-with my. partner," "I was drunk and didn't know what I was doing," "I don't 
know," "To be with my chum." Thqse who enlist because they have a liking for the military profession are of fourse the most desirable recruits. It would be impossible to arrive at any accurate opinion as to the number which enlist from this motive, as often it is not the only one.

The occupation, or want of it, which the recruit has followed before enlistment, can generally" be told with more certainty. The work of the artisan, the agriculturist, the navy;, all impress a young man with their character.

Professor Parkes, writing many years ago, estimated that out of every thousand recruits from all parts of the kingdom, labourers, husbandmen, and servants form one-half; mechanics employed in occupations favourable to physical development, one-sixth; manufacturing artisans, as weavers, cloth-workers, about onc-sixth ; the rest made up of professional occupations, students, and boys.

The previous occupation of the recruits depends a grood deal on the situation of the depôt. From my experience of those who have come up before me I would estimate their previous occupation as follows:sbout onc-half wasterels, incapable artisans, vagrants, dead-beats ; onesixth labourcrs, agricultural and navvies; one-sixth miners, iron-workers, etc.; one-sixth other professions; one-sixth or perhaps more "bounty jumpers"; the rest made up of all sorts of trade. I have found sometimes curious medleys waiting to be cxamined at the recruiting office who have asserted themselves to be grooms, clerks, waiters, musicians, architects, and some painters, broken-down artists, etc. The cause of some of them enlisting was evident. The esprit (de corps) which came from them was quite intoxicating, and I had to stand at a little distance to prevent it getting to my head. The broken-down University man, the gentleman's son, who is supposed by writers of fiction and others to enlist in the ranks and work his way up to a commission, has been a rare bird in my experience. In the south of England, at depòts which chiefly rccruit for select regiments, such enlistments may be more frequent. During some years' experience of recruiting clepots of the North, I can only remember meeting one recruit who had the characteristics of the well-born and carefully nurtured classes. He had evidently failed in some competitive examination and was trying another avenue to a successful military career. He sat looking dejected and downcast in the office, unwilling to mix with the herd of recruits in the neighbouring room, evidently very sorry for himself. He was a tall nice-looking youngster, and he went successfully through what to him must have been a rather trying ordeal. Probably he had the right stuff in him, and would obtain his commission in due course of time.

Having "passed the doctor" and been accepted by the recruiting officer, the recruit sinks out of private and civil life and becomes a unit of a small military socialism. His individuality is suppressed to a great extent; he lives, moves, and has his being in the company of his fellow units. This environment influences him powerfully for good or ill. When he returns to civil life he is like a fish out of water, lucky if he has not acquired habits which unfit him for employments which might be 
suited to the time-expired soldier, who is supposed to he, and who occasionally is, steady, orderly, trustworiny, and obedient, but who often turns out to be a worthless incapable, whom employers of labour shun.

After he has been vaccinated, whether he likes it or not, the recruit is taken in hand by various corporals and sergeants, and his physical powers are developed to an extent that is surprising to himself and to those who have seen him in the chrysalis state. That "the backbone of the Army is the N.C. man" is well exemplified at a depot. In the barrack square and at the gymnasium, squads of recruits may be seen being put through a serics of graduated exercises; bcing taught to walk, to run, to jump, to prance like a high-stepping horse, and crawl like a snake; to develop their upper limbs by various exercises with a dummy rife; with one rifle, with two; to pull thenselves up to a bar, and go through various gymnastic exercises. $\lambda$ s a result of three months' training, the recruit gains in weight and height, girth of chest and limbs. The improvement in physical development is so great that one often regrets that a similar training cannot be more universally applied, and that more of the Hooligans and youthful yahoos that infest some of the streets of our cities cannot be seized by a discerning press-gang, trained to habits of order and discipline, and their physical powers developed. Still, important and beneficial as it is, this forced phrsical culture will not supply the place of natural stamina and hardihood. Up to a certain point gymnastic exercises are of great service in increasing our physical powers. Both boys and girls who live in towns, and to whom exercises in the open air are debarred, should have a regular gymnastic training by a competent instructor. But when carried to excess the muscular system is developed at the expense of vitality. A regiment of Sandows would be magnificent on parade, and in a mêlée or bayonet charge would carry all before them, but whether they would stand the hardships and privations of a campaign as well as a regiment of Canadian lumber men (could those hardy toilers be disciplined) is doubtful. The regiment of gladiators of the time of Vitcllus Casar, idealised by Whyte MIclville, had a real existence, and died like rotten sheep in the way described when they were exposed to the hardships of war. On the whole, the raw material of the Army, what I have seen of it at least, is not quite so bad as many pessimists who speak of "regiments made up of immature lads' and so forth would have us belicve. Still, it is far from what it ought to be (considering what we have to pay for it). There are many degencrates in it. It would be found wanting in quantity certainly, were we to engage in a war with a combination of civilised Powers, or (possibly) with a single Power whose armament was up to date, who was well provided with the destructive appliances of modern warfare, and had the skill to use them. Oar work would be cut out had we to defend from attack by such as these some of the large and scattered portions of the globe over which the British flag flies. Quantity alone will not suffice. It must be combined with quality. "The thicker the hay the easier it is mowed" (a sentiment with which another Barbarian may coincide) was the contemptuous reply of the Barbarian chief to the Roman ambassador, who boasted of the number of men who 
would be brought up against the army of the Goths. "If there be any man willing to fight for honour," was the grim reply of the Highland chief, who wanted a recruit, "the price will be enough. And I want not the services of a fellow who draws his sword for gold alone."

IV $\mathrm{c}$ talk of the past, and how we have generally come out of battle broils. 'The memories of the past belong to the past. "The race which looks back, resting upon its ancient deeds, reposing on its recollections, dreaming of its ancient renown, the race or the individual who does so is infallibly lost." "Onwards," is the word; to look back is to invert the order of Nature, to wither and to die. We have chronicles of the deeds of the grand old armies of Marlborough and Wellington; we boast of them, and form more or less true conceptions of what they were like. Their material remains are a few old colours, antiquated uniforms and accoutrements, and obsglete weapons in museums and armouries. Our recent successful little wars have been against uncivilised races, armed with crude and primitive weapons, or unable to use the modern ones they liave got:hold of. We have pitted against these vary carefully selected and trained liritish regiments, backed by large contingents of alien mercenaries, all well oflicered and provided with the best approved modern armament. Could the result be doubtful? Such a force is not a sample of our whole Army. It was the practice of the Mahratta soldiers, Indian historians tell us, to ride out in front of their companies before an engagement, challenge the British officers to single combat with sword and spear, and generally overcome them. The Mahratta regiments were not made up of such as these, they were exceptional. Why should it be so difficult to recruit the rank and file of the Army with suitable men, in spite of the greatly improved condition of the soldier? If we examine the state of other occupations, which; under right conditions promote the vigour and hardihood of the race, we find they are shunned and avoided. The callings of the agricultural labourer, of the sailor, are shirked and neglected. To get our lands well cultivated, to get our mercantile marine well manned with that almost extinct species-the true British sailor-are problems which attract the attention of thinking men who have the welfare of the nation at heart. The working boys and men do not think these are good enough, and look out for softer snaps, i.e., better pay and shorter hours. Soldiering is a trade, also, which has always been despised by the Anglo-Saxon, as unworthy of a free man. He will fight, and fight well. But he dislikes discipline, and does not love the military, except occasionally in an uncertain and indiscriminating fashion.

Charles Kingsley, a typical Anglo-Saxon, expresses this sentiment in one of his books :- "A manservant, a soldier, and a Jesuit are to me the great wonders of humanity; three forms of moral suicide for which $I$ never had the slightest gleam of sympathy or comprehension." This about "sizes" it. The average Anglo-Saxon dreads the Jesuit, dislikes the soldier, and despises the nunkey.

Again, the Army is still supposed to be a "class" institution with class emoluments; the plums are unequally distributed, it is thought. Lowell has told us:- "The gin'rals get the biggest sheer, the kunnles next, 
and so on We never gut a blasted mite o' glory ez I know on; an' 'spose we hed, I wonder how your going to contrive its division, so's to give a piece to twenty thousand privits?"

'The country has become democratic, and few look on the Army as a desirable career. Nany more opportunities to emigrate are now open to the turbulent, the unruly, or the dissatisfied man, who can find no opening for his talents at home in the old ccuntry. Competing series of steamships carry him casily and at comparatively small cost to Australia, to South Africa, Canada, or whercver he may place the promiscd lan A, where wages are high and land is cheap. Often he finds it quite otherwise from what his fancy painted it. But he stays and makes the best of it, or he stays because he can't get away, or he drifts aimlessly. Seldom does he return. Occasionally "His Magnificence," who has made his pile as a Ward Politician, astonishes the village of his birth in the Emcrald Isle by displaying his grandeur for a season to the inhabitants of Ballyslachguthery. Once, such as he would have listed; now they scorn the blandishments of the recruiting sergeant. All these are reasons why it is so much more difficult to supply the rank and file of our Amy with suitable recruits. Witlin ny remembrance, the old recruiting sergeants would have laughed at the recruits who are now accepted and passed into the Army. The Army of the past had many blackguards in it no doubt, but it had fewer degenerates; the species was almost unknown then. We infer that there was more of the fighting spirit in the blackguards than in the degenerates, and it is the "spirit" that we must look for in the raw material from which our soldiers are made. "Care I for the thews, the sinews of a man. Give me the Spirit, Master Shallow," said the old Knight.

Let us hope the spirit of Corporals 'Irim and Gregory Brewster may be found in the "specials" of the present day.

Major-General F. M. BiRcil (I.S.C.):-I have followed the lecturer with much interest, but I am bound to say that I do not agree with him in a good deal. The deep thought and the high philosophy I put on one side. I have some little experience in this town with regard to the l'oor Law, and it secms to me that behind this deficiency of the physique of our recruits lies the important fact that a large part of our population is under-fed. We have too many in this country, and we cannot find empioyment for them, and it is very sad to think how these children grow up. Born from mothers who are not sufficiently nurtured themselves, they do not get sufficient nourishment in their infancy, and throughout their childhood remain in an emaciated state, which it is quite pitiable to observe. It may be quite true, as the lecturer has said, that there are other openings for employment wlich naturally would attract those who are able to fill them; but 1 am bound to say that I think there remains at spirit in the nation which in time of trouble, such as is existing now, would bring young men forward in all requisite numbers to fill the ranks of the British Army, and whatever may be the physique of these recruits-I am sorry it is not better-still Tommy Athins has shown in every recent war that he can stand up to any man that can be brought against him, however couragcous and however disciplinedwell, I do not know about discipline, but at any rate well-trained, for these Boers are certainly good shots. The recrui has never sllown himself wanting in any war as yet, I am thankful to say, that has required the interference of the British arms. I have not very much knowledge of the English recruiting, for my service has been in India; but I have heard that the recruits' characters are very much 
inquired into when they come into the Army, perhaps almost too much so. There are men who have a grand spirit-perhaps too high-spirited young men-who have come to grief elsewhere, who are quite willing to jeopardise their lives and to take up a soldier's profession. I have a son-in-law who is a recruiting officer, and from his conversation-he did not tell me this, and so I must not quote him as an authority-from his conversation it occurred to me that we were too particular in the quality of recruits we take. I can only" say that although democracy does pervade the atmosphere, it has not come into England yet, thank God. The quotation from the American author does not at all, to my mind, show the actual state of fecling in England, and in many other particulars I disagree with the lecturer

Major-General F. PEMbertox Lesch (R.E.):-I should like, with your permission, $\mathrm{Sir}$, to endorse the remarks that have fallen from the last speaker. I think that many in the audience will be extremely sorry to hate listened to the very sorry picture that has been drawn by the lecturer of the recruits of the British Army from a depôt medical officer's point of view. I can only speak as an engineer officer, and will confine my remarks to my own branch of the Service. The Royal Engineers are certainly recruited from a fairly representative class of the community, although I am perfectly willing to admit that the higher rate of pay necessarily attracts a better stamp of recruit. Officers constantly meet in virious parts of the country in grood situations men who have served under then . in the field, and by whom they are gladly recognised. The lecturer has brought forward many points to show how the recruit enters the Scrvice. No doubt there are amongst them ne'er-do-weels; no doubt there are men who are pressed by want, by a fall in the labour market, or by other causes. Nany of them, no doubt, show slight physique; but such instances are the exception, not the rulc. The gymnastic training referred to by the lecturer is excellent, and is equally useful to the trained soldier. I shall leave in your hands, Sir, one or two other points to which the lecturer has referred.

Major C. E. FAUNCE (R.A.MI.C.) :-From the medical oficer's point of view, I think as regards the point Colonel Douglas mentioned with reference to the number of rejections, that a great many of those rejections aredue to the recruits not coming up to the standard weight-the standard minimum weight of $115 \mathrm{lbs}$. There is no discretion left to the medical officer at the depôt whether he should pass a man or not. The medical officer might be able to judge that $a$ man's loss of weight is due to the fact that he has not been properly fed, and the medical officer may know that perhaps in a short time, by the good feeding at the depôt, he would get up to the required weight; but there is no discretion left to hin. We lose a large number of recruits in the Army in this way. There are a number of recruits who are passed in shown as weighing the minimum weight who are found not to come up to it when they arrive at the depôt. This, of course, is of great importance, because afterwards the weight which the recruit is said to weigh when he enlisted is entered in all his documents, and when he goes away to another station lie may get ill. Then he is weighed again and he is looked upon as having lost at great quantity of weight, when he has really not done so at all. There are lots of triclis by which recruits are brought up to the minimun standatrd of weight, such as filling them up with cold water before they are weighed. I think it should be left to the discretion of the medical officers whether they should enlist a man who is a little below the weight, and if that were done we should save a lot of men. I had a good example of this some time ago. There was a recruit who joined at Hounslow, who was shown as weighing 110 lbs. I could only make him weigh 106 lbs. I intended to have kept this recruit at Hounslow depôt for some time to see if he could be brought up to the proper weight. I happened to go away to some nanceutres, and when I cane back the recruit had gone. A short time afterwards I was sent to Malta. When I arrived there, amongst the number of patients who were handed over to me I found my friend the recruit of 106 lbs. The medical 
offeer in charge had invalided him because lle said, "Here is a recruit who has lost $10 \mathrm{lbs}$. since he enlisted." The fact was this recruit ought never to have been admitted; his loss of weight was due to his general bad physique. A number of recruits enlisted under the weight have promptly made up their weight after the training they" got at the depôt and with the good food, etc. I thini if we medical officers were left a little more discretion in that way, we should prevent the rejection of a lot of men who would make useful soldiers afterwards.

Licut.-Colonel Lord Rugi... (Royal Monnouthshire Engineers, Militia):I sloukd like to emphasise what the last speaker has said. To my nind this question is purcly a medical question. Is for laying down a hard and fest rule as to what a man should be, I think it is a very great mistake, and that it should be left entirely to the doctors who examine him. I would go farther than that. I would leave the question of age entirely to the doctor. At the present moment we lay down a hard and fast rule that a man must be eighteen, but everyone knows as well as possible that very few recruits are eighteen. A man tells you a lie with his tongue in his cheek, and you know he is telling a lie, and he knows that you know he is telling a lie, but under the present conditions you are bound to take him. I say that I should sweep away all restrictions of any sort. All I want for a soldier is a man who is physically cayable to do a certain amount of work, and the proper judge of that is the doctor. 'There is one point I sthonkld hike to call the lecturer's attention to. He has given us rather a dreadful account of recenits that we get nowadays. In the last fifty years there has grown up ir: the United Kingdom a very large force of men, the police, who are the class who enlisted fifty or sixty years ago, and the case is the same with many other tracles. I should like to say one word as to what the average recruit is before he comes to enlist. Nowadays you get the bulk of your recruits from the towins. Nearly all the boys in towns are in employment of some sort-errand boys, or messenger boys, or something. The boy lives at home; he draws his 4 s. or 5s. a week, which his mother "collars" after a scufile on Saturday afternoon. When he gets a little older he begins to feel the want of more money. He begins to walk out with his young lady. He gets tired of the weelily battle for the 5s. with his mother, and he says to his cmployer that he wants a man's wages. The employer says "You are only doing a boy's work, and 1 can yet any amount of boys to do your work!" The boy say's "Very well, I shall chuck my job and go and get a man's wages!" That boy goes out into the street and he casts about for work. He may get work; he may not. If lie does not get work he probably drifts to the barracks; and that is the history of the bulk of the recruits that join, anyhow in the larger towns. I do not see that you have a right to expect that these boys-brought up as they are, very young, very backward in development-should have the physique which you would like to get, or you should get, in men who are fit to gro through a campaign.

Lieut:-Colonel U. J. Bourke (R.A.M.C.) :--I came here. with a view of hearing something from a brother medical officer with regard to recruits. The lecture has been replete with rhetoric, etc., but I am afraid we have not got any practical ideas from it. As an officer on the Active List, I should like to dissociate myself from the tone of the remarks that the lecturer has made with regard to recruits. A special recruit is not exactly what you want, but he is a very near approach to it. You take him in, feed him well, and give the gentle gymnastic exercise that he is getting now, and he will turn out a valuable man in time. The question of standards has been mentioned, and the lecturer compares the dmerican student with the British recruil. But you nust remember that there is lluree years difference between them. If you took a British recruit at the age of the Americatn student, I am sure he would do far more justice to the Service in the time.

Dr. Docclas:- That is what I say. I say that the chief cause of the imperfect development of our recruits is the immature age at which they enlist. I think I said that in my lecture. 
Licut.-Colonel Botrke :-Yes; but the lecturer has taken the American student of 22 years of age and the British recruit at 10 , and has asised us to compare them side by side to a certain extent.

Colonel F. C. Keyser, C.B. (late Royal Fusiliers):-I think there is one way in which we ought to utilise our under-sized men, whom we now allow to go to waste and do not enlist at all-they would make beat-ideal mounted infantrymen. They are light, they are active; they are the men who generally have been employed in racing or other stables, and who, for various reasons, because they have got too heavy or something of that sort, want some other employment. They are the very men we ought to take for our mounted infantry. At present, when mounted infantrymen are wanted, the commanding officer is ordered to supply a certain number from his regiment to train at Aldershot, and he is so linited in his scope of choice that very often he has to take his very best men. Sometimes the right-hand man of all his companies goes away in order to be trained as mounted infantry. I look upon that as a decided waste. These men as mounted infantry are put on big cavalry horses, which is also a mistake. Mounted nfantry, to my mind, should be wiry, nippy little fellows mounted on 14-liand ponies, on which they could get on and off without assistance, and those ponies would carry them quite as well as horses. We should then be able to utilise a very large body of men who at present go absolutely to waste, who are longing to go into the Army, but because they are below a certain standard in height only; not in cliest measurement or in any other way, are not allowed to do so.

Surgeon-General H. S. Muir (Deputy Director-General, Army Medical Service):- I think I might say on the general question of recruits that the whole point is, What is the minimum physical standard that we want to attain to? The point bristles with difficulties. As far as I can see, we go back to different ages, and different times, and different nations. What we want to attain is the minimum efficiency that we ought to have in the British Army as a type of Briton -not as a type of the world-but as a tyje of Briton. I am in a position to say that there are enquiries on foot, and we hope shortly to have a standard which will be more adaptable, and perhaps lead to greater success in producing the supply which the demand needs. Such a question, for instance, as weight; it is perfectly intelligible. The recruit comes to us half staried. In a few weeks he will put on almost $10 \mathrm{lbs}$., and if, as a speaker has said, it is left to the medical officer (who ought to be a good judge) whether such and such a man will attain development in a few weeks, that man ought to be taken whether he is below the standard or not. The point is that we want a better guide; we desire to have an accurate table of "physical equivalents"; and I hope that object will soon be attained. As to the recruit's height, it is a different question altogether. The speaker who preceded me speaks of short men being enlisted specialty for mounted infantry. That appears to me to be quite reasonable; but when the argument is brought forward that Goorkhas-being little men-are able to shoot as well as tall men, and that rie ought to enlist shorter men than we do in the Army generally, we must recollect that the British type of manhood differs from that of the Nepaulese. It is, then, moot point whether the present standard of height should be reduced; and I hope the question will be decided before long by anthropological experts and practical soldiers.

Lieut.-Colonel Dotglas, in reply, said : - I am sorry to find myself very much in the minority; but it is a predicament in which I have often been. I have endeavoured to describe the recruit as he is actually. What my conceptions of him are is another matter. I do not mean to imply that the recruit who told me that he enlisted because he "took a notion " was a bad recruit-quite the contrary. I said in fact that these were the most desirable recruits. The undesirable ones are those who are compelled to enlist by want. I fear there are a great many of them. How many, one cannot estimate. It is only my conception that I give, when I say that there are a great many of them. As regards increased enlistment 
in time of war, all I can say is, that up to this time I have not seen it in the northern depot where I have the hon our to examine recruits. I nust say there are a better class of recruits coming forward, but the number has not, as far as I know, increased lately. It is some time since I referred to that quotatio from Kingsley, but as far as I remember he gives it as his sentiment-or one wi . which he has sympathy. Some sage has observed that he never knew an explanation that did not require more explaining than the original difficulty. Nevertheless, I will endearour to elucidate a few points that would seem to require explaining in this paper on the recruit. My observations apply to the raw material of the Army as I see it-not to the material after it has been trained, and disciplined, and drilled into fightingmen. The inference, of course, is, that the quality of the rank and file is affected by the indifference of some of the raw material. How much, how little, this is the case, it would be very difficult to ascertain. It may be that the question car. only be solved by our having to meet in warfare the army of a first-rate European Power. Assertions that my observations were a "libel on the British Army," references to the "soldiers who stormed the heights of Dargai, Glencoe, and Elands Laagtc," etc., are beside the question; I spoke of such as these in my lecture. My observations have been chiefly of the recruits of the North of England and Scotland. Of the youth recruited in London and the vicinity, who forms so large a part of the raw material of the Army, I have seen but little. At one depôt where I was stationed for some years, many recruits were sent down from London to fill vacancies, for which the district did not supply enough recruits locally. I the also visitied the recruiting office at St. George's, but not on duty. My conception of the London recruits is, that they are rather mixed, and something like the figs of the pessimist prophet: "One basket had very good figs, even like figs that are first ripe; and the other basket had very naughty figs, which could not be eaten, they were so bad. Then said the Lord unto me, 'What seest thou, Jeremiah?' and I said, 'Figs; the good figs very good, and the cvil very evil, that cannot be eaten, they are so evil.'" As far as I have gone in my examination of the raw material of the Army I have come to these conclusions : that the greater part of it is town-bred--the agricultural population yields but a small number of recruits ; that many of these town-bred youths enlist, as a last resource, compelled to do so by want and hunger; and that their physique is below the average of the youthful manhood of the same ages. How many of these there may be, what proportion they bear to those who enlist from choice, it would be hard, if not impossible, to determine. I base my conclusions on the appearance and physical condition of the youths, and the answers I receive to my enquiries, as to the cause of their enlisting. Statistics, giving the number of recruits enlisted, of those accepted and rejected, their height, weight; age, etc., are sufficiently accurate. Those relating to their previous occupations must be accepted with a certain amount of reserve. For instance, in my own experience, a youth, whom I knew to be a "sale's clerk" in a store, when he came up for examination for cnlistment, was relurned as an "engineer," a couple of golf caddies as "labourers," a dock loafer as a "seaman," etc. Of course, it is nearly impossible to verify each youth statement as to what he has worked at, or whether he has worked at all. "Between vague, uncertain, 'capability' and fixed absolute performance, there may be a great gulf." Lastly, may not the observations of an elderly medical officer of some experience of life in its various phases, who would probably better serve his interests by keeping silent, who has no cause to grumble, no reason to speak ill of a Service which has treated him better than he deserves, carry some weight, beside the opinion of those, who as far as he knows, see but little of the soldier in the chrysalis stage, and who may picture to themselves ideal recruits, quite different from the rea ones. Utcrum creditis Romani? Which of the two will you belicve, oh Britons?

Colonel CARLEToN :-Charles Kingsley said that food for powder unfortunately required to be very good food. 
The Cunirusax (Major-General J. F. Maurice):-I think that it is exceedingly valuable to us to have a question of this kind brought before us in the most complete form it can be, and I may say that without partiality, favour, or affectation, because I do not think I have ever passed through such an uApleasant hour as I have in listening to my friend Colonel Douglas. We are to $i$ on high anthority that such discipline is good for one. I am bound to say it may have been very improving, but it certainly was very severe. I scarcely agree with any single syllable that he said from the beginning of his lecture to the end. As for his main point, the spirit which he says is wanting in the British race-

Colonel Dolglas :-No. Martial spirit may be wanting in some of the recruits.

The Charmax :-It is wanting, surely, according to your statements, in the race. Let me take the lecturer's quotations. It seems to me they represent the mistake he made throughout his lecture. He quoted from Charles Kingsley, but Charles Kingsley was a dramatist, and in that quotation he is representing a particular type of character-a tailor. It does not bear a trace of Charles Kingsley's own opinions. I knew Charles Kingsley well. There was no man who loved soldiers more, and there was no one whom soldiers loved more. But he was much too good a dramatist not to be able to put into other men's mouths that which he in no way shared himself. The lecturer has quoted these long passages of forty years ago, and he says we are to judge of the present by them. Heavens ! Haven't we had enough in the last two or three years to disprove that? Is Dargai nothing? Is what has been going on in South Africa nothing? Is it not a question of to-day what the British soldier is? Somebody said in one of the papers-and I am bound to say I agree with him from all I have ever seen of fighting-"Give me Tommy Atkins to lead, and you may have anybody else you like." As to the question of the motives that induce people to enlist, the author says they enlist for gold. Because the men come in and take the very lowest pay you can possibly give to a man to live upon, the lecturer says they enlist for gold. That simply means that we do not compulsorily enlist; but the lecturer does not suggest that we should go in for compulsory enlistment. As to the tendency of the country and the readiness of the men whom we enlist, when 80,000 men a year come and offer themselves for enlistment, surely that has a most important bearing on the extent to which the Army does still possess attractions for the Anglo-Saxon. And it is a yet more striking fact that the recruiting has doubled within the last few weeks-it has more than doubled, it has nearly trebled since active service began. The thing which the Anglo-Saxon does not like is the ordinary life of a soldier in peace-time. It is very natural that he should not like it as long as he only knows it through these expressions of Kaye's and the like, quoted in the country by people who have known nothing of the Army for years, wrongly impressing the public, influencing mothers and influencing the clergy. Of course, as long as you have them dead against you there will always be a reluctance of a certain kind to cnlist for the ordinary work of a soldier in peace-time. But we have never yet had the slightest objection on the part of the Anglo-Saxon to enlist during war. The moment war breaks out he wants to go. Unfortunately, the difficulty is to persuade him that he has to be trained for war. What is the lecturer's own story of the question he puts to the recruits? He asks them, "What makes you enlist?" It is a matter of absolute astonishment on the lecturer's part that anybody should be such an utter fool as to enlist. He does not mean to put it to the recruit in that way, but he has the consciousness that it is so. Remember this : the Briton-not the soldier only, but the Briton-is a dumb animal. We always have been so. All the valour of the Briton has been dumb valour. The lecturer asks the recruit this question, and gets the answer, "I took a notion." The recruit is ashamed to say, "I enlisted because I wished to fight for my country." It is not in the nature of the Briton to say that; he is much too modest. He does not like to come out with high-falutin terms; he hates it, and he will find any excuse not 
to say it. Ithy did he not come a few weeks ago, and why does he come now? He comes because he wants to fight. The reason he does not come in peace-time is that he has an inpression of the nature of the Service and of the nature of the men whom he will meet there, which is produced by such slanders as those of Kaye's, and by the wrong ideas prevailing in the country, which were started in the last century by people-I cannot put into language what I think of them; I dare not trust my'self-who emptied the gaols into the Army, and of course we have never got over the impression which that created among a large portion of the population. They gave us gaol-birds instead of yeomen, whom we had had up to that time, and we have still to shake off the ball impression created by that fact. As regards the quality of the recruit that we get, we are alway's fighting to improve it, and in proportion as we get rid of sucls slanders as those of Kaje's, in proportion as we get people who do not take the vicw that the lecturer does of the recruit, so shall we get the men we want to come in. It may well be that we shall have to offer yet greater induucements-we cannot go on improving the conditions we offer to the recruit too nuch. But when the country is in such a humour as it is at present I cannot admit that the Anglo.Saxon shows any signs of not liking the soldier. It has alway's been the case in every country that when there is war the soldier is loved. The AngloSaxon always imagines his is going to be the most peaceful country in the world, but he is always going to war." Ditring peace-time he imagines he does not want the soldier, because he is going to be such a peaceful animal and won't quarrel again; he hates to pay for no purpose at all. But at the present moment it seens to me that the whole country is simply teeming over with regard for the soldier. I do not think that the lecturer's representations come into it at all. When you come to the practical details of the question, I admit that there are a number of points that need improvement. The lecturer talks about men, but he omitted one whole class in the Army-the best class-that is, the boys. If the feeling of dislike of the Army by those who serve in it, which has been asserted by the lecturer to exist, were something real and not an outside impression-an impression which is representative of the very spirit that is our great difficultywhy is it that the very best recruits we get are the sons of old soldiers, who come to us year after $y$ ear? In every branch of the Service that is so. So far from having any difficulty in recruiting the sons of those who know the Army best, we cannot take much more than a third of the boy's whom we could enlist if we were able to take then. They come in and make our very best soldiers, and that is proof positive that it is not something inside the $\Delta \mathrm{rmy}$, but a general vague impression outside that stands in our way. The 80,000 recruits who offer themselves every year-a most extraordinary fact, which you would not get in any other country in the world-are not all of the best type, but when war breaks out then the recruits that come in are splendid. As General Leach and Colonel Keyser have pointed out, the question of size and everything of that kind is almost entirely one of the particular branch of the Army that you require a man for. I have never been able to understand why you want for an infantry soldier at the present day. anything mose than stamina, power of endurance, health, strength, good teeth and eyesight, and all that kind of thing, but what is the use of a huge man in the practical conditions of fighting I am absolutely unable to understand. Nor do we want it in the least for drivers in the artillery. On the other hand, we do want large gunners, because they have to lift heavy weights, which small men could not do. Then with regard to mounted infantry, it secms to me that what Colonel Keyser says is true. You can do with a very much smaller man provided he has strength and health. Colonel Bourke made a point $I$ had intended to make about the comparison of those two men-the Englishman and the American recruits. There was a serpent lying hid beneath that comparison, which I have just got from Dr. Douglas. His great idea is that we enlist our recruits too young. The answer to that is, that with voluntary enlistment we 
have to take the men when we can get then. It would be very nice to do what the Germans do, viz., go into the country and say we are going to have all the men at 90 and 21 years of age unless they are not up to the standard. But we cannot get them at that age before they have passed into trades in the country, we could only get the failures of other trades. If we enlisted at 20,2 or 22 , everything that Dr. Douglas says would be true. As boys you can get them, because they want to go into the Army. As they get older and older they get more settled in trade, and you can only get the nger-do-wells and make-shifts. That phrase "I took a notion" is a much more representative fact with a good many of them than Dr. Douglis at all realised; he should give credit for something beneath it. It means a real love of an adventurous career, and the thought that he is doing work for England, and has a pride in England. I think that is much nearer the mark than Dr. Douglas's view. Dr. Douglas speaks of our recent gymnastic exercises, and of the Sandow system in particular. - I am sure everybody' who has watched it will support everything General Leach has been saying. Is far as my observation goes, anything more splendid than the effect of the training in the infantry depots at the present time on the recruit cannot be conceived. I have been fighting all I know to get the same principle-at least three months for that development-applied to the artillery recruit, although he has nothing whatever to do with the absolute cxercises afterkards. It means healti, strength, and everything else. I look upon that gymnastic training as in every respect the best preparation for making warriors that we can have. The lecture has been exceedingly valuable to us, becatise it has brought out so excellent a discussion, and such perfect unanimity in rejecting the conclusions of the lecturer.

Colonel G. Carletox (late R.A.) :-With your permission, Sir, I should like to say something with reference to your own remarks now. I was one of the officers during the Crimean war authorised to enlist men for the Osmanli Horse Artillery. I had 160 recruits at Woolwich; they were some weeks there in camp, quite young fellows. Every man wishing " , enlist had to come with a satisfactory character, enlistment was for two yearst $l$, if required, the term was to tee pro. longed for one year more. Every candin had also to be able to ride. There was, with the exception of the ordinary lit ; as to age, particulars of which $I$ do not now clearly recall, no other qualificatioit so far as I remember. The recruiting officer had only the power to choose men of suitable and limited height and weight. Each man got 2s. a day pay with uniform and rations free. Any number of men could have been had with the above qualifications, I suppose. The recruiting was stopped in three weeks. There were more men than were wanted. I had a crowd of respectably dressed young fellows about the house where I was living in Dublin, that is, after three or four days when the Government offer became more known; but when I first went to the different livery stables and read the terms. above stated, I was, I could see, not fully trusted, the terms were considered too good to be true. I relieved an officer at Woolwich, who was in charge of a large number of recruits already enlisted in London; he told me he had promised leave to go home and say grood-bye to their relations to nearly all the young fellows he left with me, and he hoped I would let them go. I did so, and advanced them the money to pay their railway fare in some cases, and to several I advanced small sums besides to leave with their parents. I explained to all who thus got leave the serious position I should be in if they did not return at the end of the two or three days they had leave for. Not one of them disappointed me.

The Chalkmax :-That was in war-time, I think your said?

Colonel Carleton:- Yes. I give this, Sir, as corroborative of your remarks about the impulse to recruiting that war gives in our country. 